\title{
Культ Белого старца (монгольские тексты из Тувы)
}

\author{
Баазр А. Бичеев \\ Независимый исследователь, Российская Федерация; \\ Алтан-Очир
}

Институт приграничных территорий Академии общественных наук КНР, Китайская Народная Республика

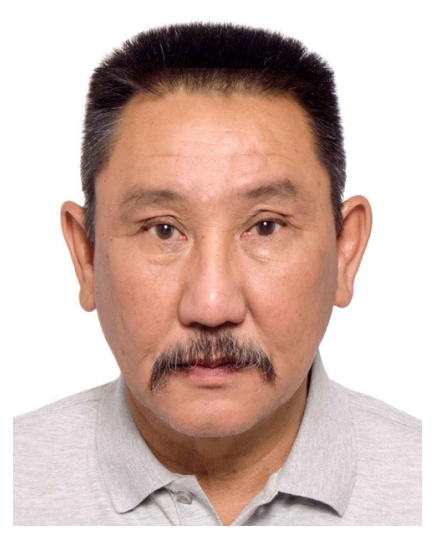

Одна из богатейших обрядовых, текстологических и иконографических традиций сложилась вокруг культа Белого стариа. Широкая распространенность и значимость культа делают его особым феноменом религиозно-духовной культуры монгольских народов.

В статье дан обзор монгольских текстов молитв-сангов и «Сутры Белого старца» из фондов Национального музея им. Алдан-Маадыр Республики Тыва. В рукописном фонде музея находится одиннадцать рукописей, из которых нам удалось ознакомиться с пятью текстами. Рукописи из Тувы представляют интерес и как региональная традиция культа Белого стариа, так и с точки зрения текстологии.

Одной из особенностей графики текстов из Тувы является то, что в большинстве текстов графема š во всех позициях отмечена короной (титм), что является характерным признаком «ясного письма».

Ключевые слова: Белый старец; молитва-санг; «Сутра Белого старца»; рукописный сборник; текстологическая традиция; Тува

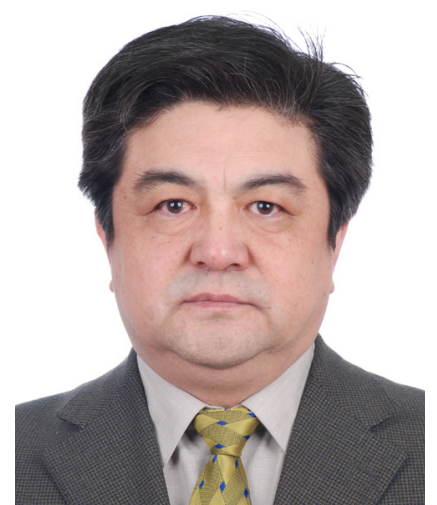

Финансирование

Исследование выполнено при финансовой поддержке РФФИ и Академии общественных наук Китая в рамках научного проекта № 20-512-93002.

\section{Для цитирования:}

Бичеев Б. А., Алтан-Очир. Культ Белого старца (монгольские тексты из Тувы) // Новые исследования Тувы. 2021, № 1. C. 174-187. DOI: https://www.doi.org/10.25178/nit.2021.1.9

Бичеев Баазр Александрович - доктор философских наук, независимый исследователь; главный редактор серии «Corpus scriptorum oiratorum». Адрес: 358000, Россия, г. Элиста, ул. А. М. Горького, д. 18. Тел.: +7 (961) 394-55-64. Эл. адрес: baazr@mail.ru

Алтан-Очир - доктор исторических наук, профессор Института приграничных территорий Академии общественных наук Китайской Народной Республики. Адрес: 1 Goujia tiyu chang beilu, Chaoyang Distr., Beijing 100101, People's Republic of China. Эл. адрес: altan.ochir@yandex.ru

BICHEEV, Baazr Aleksandrovich, Doctor of Philosophy, Independent researcher; Editor-in-chief of the Corpus scriptorum oiratorum series. Postal address: 18 A. M. Gorky St., Elista, 358000, Russia. Tel.: +7 (961) 394-55-64. E-mail: baazr@ mail.ru ORCID ID: 0000-0002-9352-7367

ALATENG AOQIER, Doctor of History, Professor, Institute of Chinese Borderland Studies, Chinese Academy of Social Sciences. Postal address: 1 Goujia tiyu chang beilu, Chaoyang Distr., Beijing 100101, People's Republic of China. E-mail: altan.ochir@yandex. $\mathrm{ru}$

ORCID ID: 0000-0002-6419-0531 


\title{
The cult of the White Old Man: Mongolian texts from Tuva
}

\author{
Baazr A. Bicheev \\ Independent researcher, Russian Federation, \\ Alateng Aoqier \\ Institute of Chinese Borderland Studies, People's Republic of China
}

\begin{abstract}
One of the richest ritualistic, textual and iconographic traditions is associated with the cult figure of the White Old Man. Its popularity and significance makes it a remarkable phenomenon in the religious and spiritual culture of Mongolians.

The aim of this article is to give an overview of the Mongolian texts of sang-prayers and of the "Sutra of the White Old Man", which are a part of the collections of the Aldan Maadyr National Museum of the Republic of Tuva. The manuscript collection of the museum boasts of eleven such manuscripts, and five of these, examined by the authors, are presented in this publication. The Tuvan manuscripts are of special interest as illustrative of the regional tradition of the White Old Man worship, but also in terms of the textual studies.

One of the features of the graphics of Tuvan texts is that the grapheme š is in most cases marked with a crown (titm) in all positions, which is a typical feature of "clear script".
\end{abstract}

Keywords: Worship of the White Old Man; texts of sang-prayers; "Sutra of the White Old Man"; manuscript collection; textual tradition; Tuva

\section{Введение}

В пантеоне буддизма низший разряд божественных существ составляют древние религиозные культы, ассимилированные в ходе утверждения буддизма среди разных народов. Одним из таких ассимилированных древних культов является Белый старец.

Под разными именами он известен в религиозной системе народов Дальнего Востока, Центральной Азии и Сибири. В Японии его называют Дзюродзин, в Китае - Шоу-син, в Тибете - Гамбо Гарбо. В Монголии он Цагаан эбуген, в Бурятии - Саган убугэн, а в Калмыкии у него несколько имен - Цаган аав, Цаган авга, Цаган буурл эбуген, Делкен эзен Цаган аава (Хозяин мира Белый старец). В калмыцких храмах его почтительно называли Когшин-богдо (Святой старец). При всем разнообразии имен Белого старца у монгольских народов, в письменной традиции он известен под одним общим и неизменным эпитетом Усмиритель и покоритель [духов-хозяев] земли и воды (

Судя по сохранившимся многочисленным спискам монгольских и ойратских текстов, посвященных культу Белого старца, это был широко почитаемый образ древней добуддийской религиозной системы. В научный оборот текст «Сутры Белого старца» ввел А. М. Позднеев. Выделив несколько основных положений относительно этого культа, он опубликовал русский перевод монгольского текста «Цага̄нэбӱгэну судур» («Учение о Цага̄н-эбйгэне») и отметил, что эта псевдосутра была написана буддийскими ламами в позднее время для ассимиляции древнего культа в ранг местных защитников буддизма, давших клятву не вредить буддизму и защищать его сторонников (Позднеев, 1887: 83-85).

Письменная традиция, сложившаяся вокруг культа Белого старца, подразумевает два вида текстов. Во-первых, псевдобуддийскую сутру. Во-вторых, обрядовые тексты молитв-сангов или воскурений, 
которые читались во время жертвоприношения Белому старцу и кормления на обо многочисленных ландшафтных сверхъестественных существ - духов-хозяев земных и водных пространств.

Обо как непременное место проведения обряда жертвоприношения, на котором совершалось призывание, подношение, кормление и молитвенное обращение к Белому старцу и/или сонму хозяев той или иной местности, является древней добуддийской традицией. Исследователи отмечают, что просто культа обо, т. е. поклонения куче камней с воткнутыми в нее ветками деревьев (или какой другой форме обо), не существует отдельно от культа почитания духов-хозяев местностей (Герасимова, 1980: 76).

С бытованием этих двух видов текстов связана храмовая и светская обрядовые традиции их чтения во 2 и 16 день лунного месяца, а также во время массовых молений на обо в дни народных празднеств. В сознании верующих оба текста воспринимались как нечто целое, объединенное одним культом. Поэтому часто на титульном листе сутры может быть указано, что это молитва-санг, и, наоборот, на титульном листе молитвы могло быть написано, что это сутра.

Цель данной статьи ввести в научный оборот часть текстов, находящихся в фондах Национального музея им. Алдан-Маадыр Республики Тыва (далее - HМ РТ) и сопоставить их содержание с опубликованными исследователями образцами подобного вида. В фондах музея хранится 11 рукописей, представляющих два вида текстов. Текстуальный корпус, связанный с культом Белого старца, требует дальнейшего его изучения. Поэтому рукописи из Тувы представляют интерес и с точки зрения текстологии и как свидетельство универсальной традиции культа Белого старца, существовавшей на огромном культурном пространстве Сибири и Монголии.

\section{Два вида текстов культа Белого старца}

Корпус текстов, связанный с культом Белого старца, как было отмечено, состоит из двух видов прозаической псевдобуддийской сутры и стихотворных обрядовых текстов молитв-сангов. Прозаический текст сутры был предназначен для утверждения культа Белого старца в многочисленном ряду местных защитников, давших клятву защищать буддизм и его последователей. Несмотря на большое количество списков этого текста, все они имеют одинаковый сюжет, в котором повествуется о встрече Будды и Белого старца на горе под названием Фруктовая (zemeseleng). Во время этой встречи Белый старец дает клятву защищать все живые существа. Будда в свою очередь наделяет его особой мантрой, тем самым утверждая его в ранге местного защитника буддизма. Стихотворные тексты молитв-сангов, которые читались во время обряда жертвоприношения Белому старцу на ‘обо’, в отличие от текста сутры представляют разные типы текстов. Их содержательная часть, хотя и была выстроена по определенной форме, могла легко варьироваться в зависимости от региональной обрядовой традиции.

С бытованием этих двух видов текстов связана храмовая и светская обрядовые традиции их чтения во 2 и 16 день лунного месяца, а также во время массовых молений на обо в дни народных празднеств. В сознании верующих оба текста воспринимались как нечто целое, объединенное одним культом. Поэтому часто на титульном листе сутры может быть указано, что это молитва-санг, и, наоборот, на титульном листе молитвы могло быть написано, что это сутра.

Два вида этих текстов, связанных с культом Белого Старца, были опубликованы В. Хайссигом, которой впервые предложил их классификацию. Исходя из доступных ему материалов, В. Хайссиг предложил следующие этапы эволюции текстов молитв-сангов и «Сутры Белого старца»:

1. № XIX Молитва «Белому старцу» (монгольский текст молитвы-санга),

2. № XX Молитва «Белому старцу» (монгольский текст молитвы-санга),

3. № XXI Молитва «Белому старцу» (ойратский текст псевдосутры),

4. № XXII Воскурение «Белому старцу» (ойратский текст молитвы-санга),

5. № XXIII Молитва «Белому старцу» (молитва-санг Мерген-гегена) (Heissig, 1966: 21).

Предложенная В. Хайссигом классификация была дополнена Х. Футаки на основе широкого круга источников из Монголии и Китая. Всего он выделил девять типов текстов:

Тип А: молитва-санг, составленная Мерген-гегеном [Heissig № XXIII],

Тип A1: вариант типа А с дополнительными стихотворными вставками,

Тип В: обращение, имеющее тибетский эквивалент [Heissig № XIX],

Тип В1: вариант типа В с дополнительными стихотворными вставками сельскохозяйственного характера, 
Тип C: псевдобуддийская сутра [Heissig № XXI],

Тип C1: вариант типа C со стихотворными вставками из типа B,

Тип D: молитва, связанная с культом гор Утай,

Тип E: руководство по освящению, используемое бурятами,

Тип F: молитва-санг, использовавшася ойратами [Heissig № XXII] (Futaki, 2005: 38).

Культ Белого старца продолжает оставаться в поле зрения исследователей Монголии и Китая. Известно, что самая большая коллекция рукописей на старомонгольской графике и «ясном письме» хранится в рукописном фонде Института языка и литературы АН Монголии. О. Самбудорж опубликовал каталог молитв-сангов из ойратской коллекции института. В пятом разделе «Молитвы-санги [хозяевам] земли и воды» («Уул усны сан») он приводит описание 27 текстов сангов и «Сутры Белого старца» (Самбудорж, 1997). Из современных работ следует указать на статью С. Дулама, где на основе собранного полевого материала раскрываются традиции обрядового моления Белому старцу у монгольских бурят (Дулам, 2018).

Последние два десятилетия монголоведы Китая ведут активную деятельность по поиску и публикации рукописей на «ясном письме». Хранитель ойратской коллекции г. Урумчи До. Галдан издал сборник текстов под названием «Стихотворные поучения и молитвы-санги» («Suryal šilüg kiged sang takil»). Среди других опубликованных в этом сборнике текстов есть и факсимиле молитв-сангов и «Сутры Белого старца» (Galdan, 2013).

Профессор Центрального университета национальностей М. Эрдэмт с 2015 г. по 2019 г. издал 50 томов серии «Исследование памятников “ясного письма”, хранящихся в верховьях реки Или» («Ili-

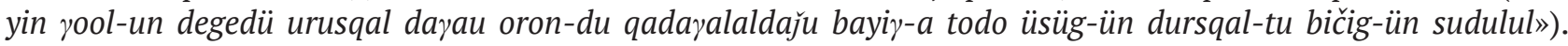
В серии опубликовано факсимиле более ста рукописей, в том числе и десять текстов «Сутры Белого старца» (Erdemtu, 2015-2019).

Среди неизвестных исследователям текстов следует указать на монгольские рукописи молитвсангов и «Сутры Белого старца», находящиеся в фондах НM РТ. Согласно каталогу, составленному А. Г. Сазыкином, в фондах музея хранится 11 текстов - «Cult of the White old man: No. 15, 220, 300, 323, 324, 389, 479, 480, 620, 781, 905» (Sazykin, 1994: 329).

Нам удалось ознакомиться только с содержанием пяти следующих рукописей ${ }^{1}$ :

М-15. «Молитва-санг Белому старцу»

л. 1r. Ča $\gamma$ an ebügen-ün sang ene bui.

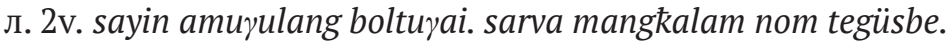

Монг. рукопись, 2 л., 17.8×7.5, 14 стк., рус. бумага, черная тушь, калам.

M-220. «Сутра святого Белого старца. Сутра санга».

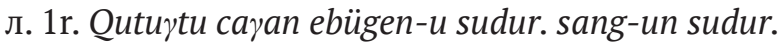

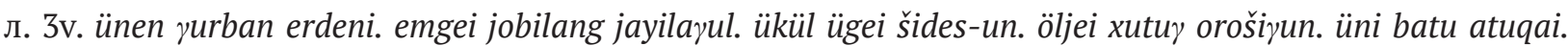
sarva mangkalam.

Монг. рукопись, 3 л., 21×7.5, 12 стк., рус. бумага с филигранью «Фабрика Бр. Ятесъ № 7», черная тушь, калам.

M-300. «Сутра-санг Белого старца»

л. 1r. Čayan ebügen-ü sang-un sudur orosiba.

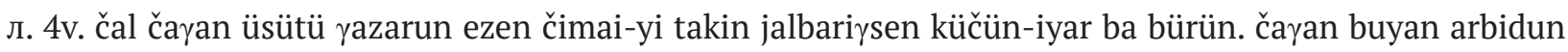
delgerituqai. mang kha laṃ.

Монг. рукопись, 4 л., 22×8, 15 стк., рус. бумага, черная тушь, калам.

${ }^{1}$ Условные знаки и сокращения, используемые при описании рукописей: л. 1r. - лицевая (recto) сторона листа; л. $2 \mathrm{v}$. - оборотная (verso) сторона листа; $17.8 \times 7.5$ - размер листа рукописи в сантиметрах; мон. рукопись монгольская рукопись, 2 л. - общее количество листов рукописи; 12 стк. - общее количество строк на одной стороне листа; рус. бумага - русская бумага. 
M-323. «Шастра под названием “Молитва-санг Белому старцу”»

л. 1r. Ča a an ebügen-nü sang neretü sašitar.

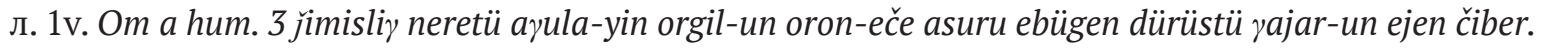

л. 3r. namova budadhai-a namova dharamai-a namo va sankhai-a enedkey-un keleber ju suve ha töbed-un keleber

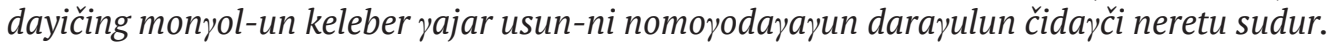

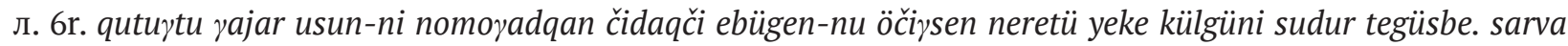
mam kha lam.

Монг. рукописный сборник, 6 л., 22×8.5, 21 стк., рус. бумага с филигранью Успенской фабрики, черная тушь, калам.

M-324. «Сутра под названием молитва-санг Белому старцу»

л. 1r. Ča yan ebügen-nü sang neretü sudur orošiba.

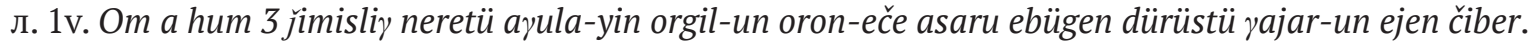

л. 3v. namo va budadai-a namova daramai-a namova sankai-a enedekey-un keleber suva sha töbed-un keleber

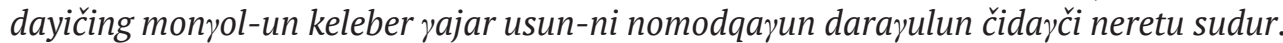

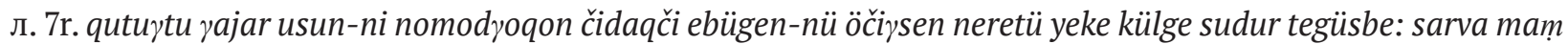
kha lam.

Монг. рукописный сборник, 7 л., 21.5×8.5, 17 стк., рус. бумага, черная тушь, калам.

В каталоге А. Г. Сазыкина указаны наименования еще шести текстов:

M-389. Čajan ebügen-ü sang orošibai (la).

Монг. рукопись, 3 л., 17.5×7.5, 17 стк.

M-479. Ui-tang-sang-yin tabun Manjuširi ča

Монг. рукопись, 3 л., 22×8.8, 16 стк.

M-480. Ča

Монг. рукопись, 3 л., 22×8.8, 22 стк.

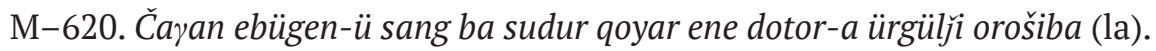

Монг. рукопись, 31 л.+1 л., 11×4, 7 стк.

M-781. Aldar ča

Монг. рукопись, 2 л., $22 \times 8.5,15$ стк.

M-905. Ča $a$ an ebügen-ü sang ba sudur qoyar ene dotor-a ürgülj̆i orošiba (la)

Монг. рукопись, Лл. 1-2, 4, 6-8, 17.5×6.5, 12 стк. (Sazykin, 1994).

При ближайшем знакомстве с содержанием пяти тувинских рукописей выяснилось, что в них содержатся тексты пяти молитв-сангов, известных по классификации В. Хайссига и Х. Футаки и двух «Сутр Белого старца».

\section{Структура текстов молитв-сангов}

Подавляющая часть текстов сангов выстроена по одному принципу. Вначале следует обращение к многочисленным буддам и божествам проявить милость и явиться к месту подношения на обо, т. е. к месту, где совершается подношение. Затем следует просьба принять подношение. В основной части высказывается просьба о защите и покровительстве, а в заключении произносится благопожелание. По такому же принципу выстроены все известные нам тексты молитв-сангов Белому старцу, в том 
числе и тексты из НМ РТ, которые состоят из нескольких разделов, последовательно вытекающих одна из другой.

\section{I. Формула поклонения.}

Согласно традиции, каждый текст санга, как и любого другого сочинения религиозного содержания, должен открываться формулой поклонения. Это может быть как формула поклонения Трем драгоценностям, так и любому из будд и бодхисаттв.

\section{II. Призывание Белого старияа и других божеств.}

Текст молитвы начинается с приглашения будд и бодхиссатв 24-х сторон, Белого старца и сонма духов-хозяев местностей на обо. Буддийские комментаторы делят все персонажи буддийского пантеона на четыре уровня «гостей», призываемых для обрядового угощения. К высшему уровню относятся все будды и бодхисаттвы. Ко второму уровню «защитники, заслуженные гости» относятся ассимилированные буддизмом индийские культы (дака и дакини, дхармапала, гобпо). В третий уровень «добрых милостивых гостей» входят тибетские культы, типологически сходные с верованиями монголов (покровители скота, хозяева земли, жилища, очага и др.). В нижний уровень входят злые духи (гон, гэг, ланчаги) (Ламаизм в Бурятии ..., 1983: 154-155).

III. Выражение почтения Белому стариу и другим божествам.

Вслед за приглашением следует призыв принять восемь традиционных подношений (воду для питья, воду для омовения, ароматную водау, цветы, благовония, лампадку, пищу, музыку), шесть видов превосходных лекарств (мускатный орех, зеленый кардамон, черный кардамон, гвоздику, шафран, манну бамбуковую), драгоценности (золото, серебро, жемчуга) и др.

IV. Восхваление Белого стария.

В этом разделе молитвы присутствует связь с содержанием «Сутры Белого старца». Дается описание его внешнего вида, упоминается его клятва помогать всем живым существам, произнесенная перед самим Будды на горе Плодовой (Фруктовой). Иногда в этой части могут быть перечислены те деяние, которые присущи Белому старцу (запись благих и греховных деяний людей, способность избавлять или насылать несчастия на людей и др.).

\section{V. Обращение с просьбой к Белому старцу.}

Это основной раздел содержания молитвы. Он представляет собой просьбу, обращенную к Белому старцу, т. е. то, ради чего устраивается подношение Белому старцу и кормление многочисленных духовхозяев местностей. Традиционно здесь высказываются стандартные просьбы - устранить причины несчастий и болезней, даровать здоровье и долгую жизнь, способствовать увеличению поголовья скота, установить мир и спокойствие. Иногда это могут быть просьбы избавить от дурных предзнаменований: крика птиц, разбитой посуды, ссоры, воя волка и лая лисы и др. (Śarközi, 1983).

\section{VI. Благопожелание.}

Текст молитвы завершается традиционным благопожеланием, в котором высказывается пожелание широкому распространению веры в Три драгоценности, установления прочной светской власти, благополучной и счастливой жизни.

VII. Заключительная формула.

Традиционно это либо известная мантра шести слогов и/или санскритская формула всеобщего блага sarva mam gha lam.

По такой достаточно простой схеме композиционно выстроены тексты молитв-сангов Белому старцу. Однако такие тексты отличается высокой вариативностью, поскольку сама конструкция при всей ее жесткости позволяет дополнять, сокращать, изменять содержание разделов, исходя из тех или иных требований региональной традиции. Поэтому любая классификация текстов молитв-сангов Белого старца достаточна условна. По мнению А. Бирталан, главной характеристикой монгольского корпуса текстов санг является то, что он унифицирован, построен из схожих текстовых модулей, которые варьируется в зависимости от традиции (Birtalan, 2020: 276).

\section{Рукописи молитв-сангов и «Сутры Белого старца и из НМ РТ}

Во всех пяти исследованных нами рукописях из Тувы содержатся тексты молитв-сангов Белому старцу. При этом три рукописи представляют собой отдельные тексты молитв-сангов, а две одругие рукописные сборники, состоящие из текста молитвы-санг и «Сутры Белого старца». 


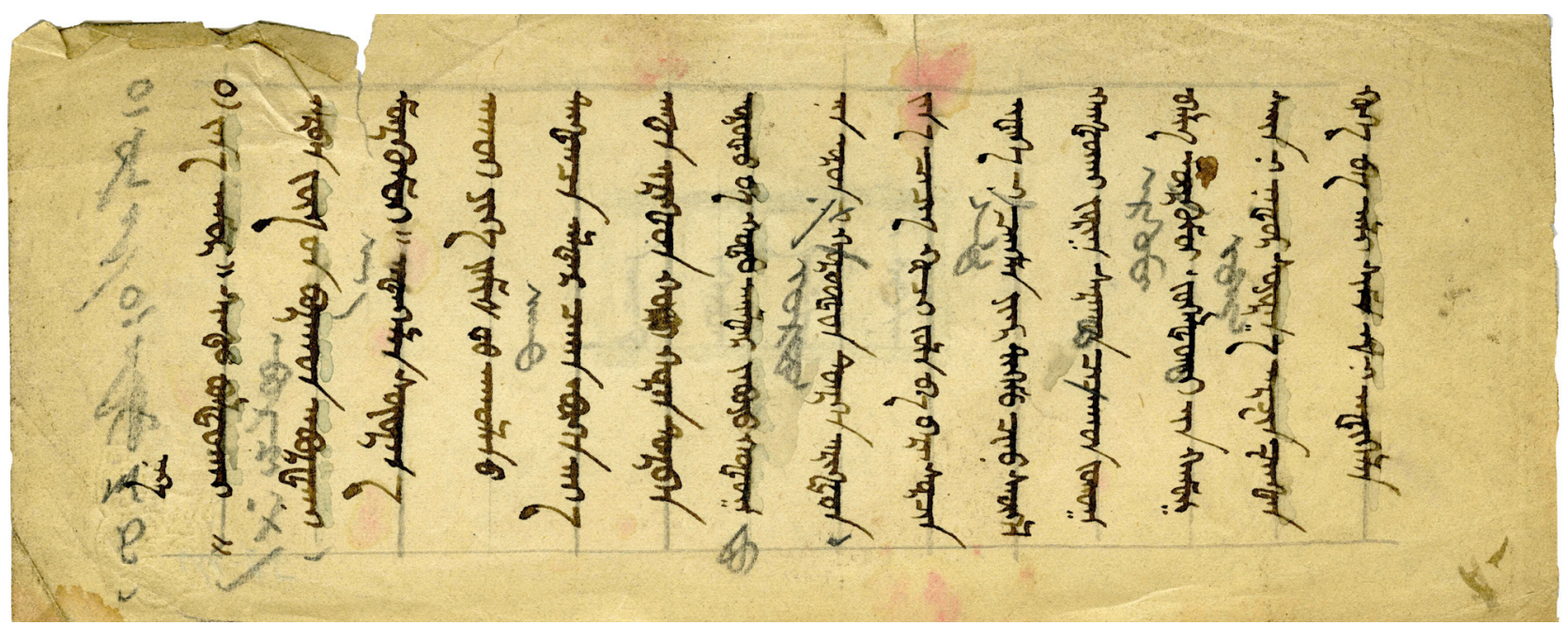

Фото 1. Лист 1v. рукописи М-15 «Молитва-санг Белому стариу». Из фонда Национального музея им. Алдан-Маадыр Республики Тыва. Photo 1. Page 1v. of the manuscript M-15 «Prayer-sang to the White Old Man». From the collections of the Aldan Maadyr National Museum of the Republic of Tuva.

Небольшая по объему рукопись М-15 «Молитва-санг Белому старцу» («С̌a bui») соответствует тексту № XXIII в публикации В. Хайссига и типу А (Молитва Мерген-гегена) по классификации Х. Футаки.

Сведений о дате рождения и смерти Мэргэн-гегена (геген Мэргэн-лама, геген Мэргэн-диянчи-лама, хубилган Мэргэн-диянчи, Мэргэн-диянчи-лама) нет. Известно лишь, что он был одним из монгольских перерожденцев высокого уровня и занимался переводами на монгольский язык тибетских текстов культа докшитов, составлением обрядников жертвоприношений хозяевам земли и водных источников, Белому старцу и божеству горы Мунахан. В 1780-1783 гг. в Пекине были изданы четыре тома его сочинений, в том числе и молитва-санг Белому старцу (Futaki, 2005: 38).

Текст рукописи М-15 имеет незначительные расхождения с текстом Мэргэн-гегена. Имеются различия в написании слов, пропуска строк, а также наличие строк, которых нет в публикации В. Хайссига.

Приведем для примера два первых раздела молитвы.

\begin{tabular}{|c|c|c|}
\hline$M-15$ & $\begin{array}{c}\quad{ }^{N o} \text { XXIII } \\
\text { (Heissig, 1966) }\end{array}$ & Перевод \\
\hline \multicolumn{3}{|c|}{ I. Формула поклонения } \\
\hline Om. Amur: sayitu bolturai: & Om. Amur sayitu bolturai. & Ом. Да пребудет благоденствие! \\
\hline $\begin{array}{l}\text { Arban jüg-ün burqad } \\
\text { Aburdani mörgümüi: }\end{array}$ & $\begin{array}{l}\text { Arban jüg-ün burqad-tur } \\
\text { Abaridan mörgümü. }\end{array}$ & $\begin{array}{l}\text { Буддам десяти сторон } \\
\text { С мольбой о защите преклоняюсь! }\end{array}$ \\
\hline Adislan soyorq- $a$. & Adislan soyurqa. & Соизвольте благословить! \\
\hline \multicolumn{3}{|c|}{ II. Призывание Белого старца и других божеств } \\
\hline 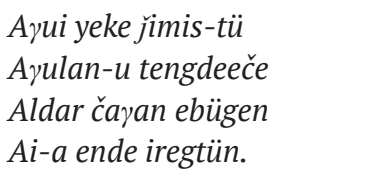 & 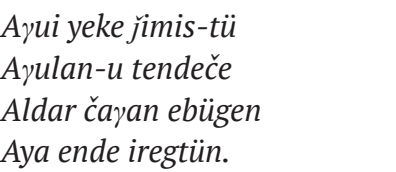 & $\begin{array}{l}\text { С великой горы Земисту, } \\
\text { С места своего обитания, } \\
\text { Славный Белый старец, } \\
\text { Соизволь явиться сюда! }\end{array}$ \\
\hline
\end{tabular}




\begin{tabular}{|c|c|c|}
\hline 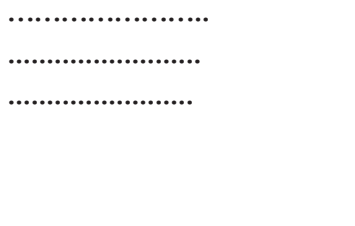 & 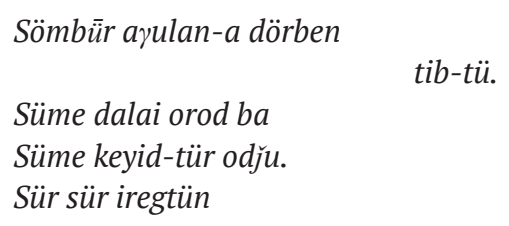 & $\begin{array}{l}\text { С четырех континентов горы } \\
\text { С земель Мирового океана, } \\
\text { Собравшись в храмы и монастыри, } \\
\text { Сонмом явитесь [сюда]! }\end{array}$ \\
\hline $\begin{array}{l}\text { Qorin dörben orodu ba } \\
\text { Qotu ayildar yabuču } \\
\text { Qutuү ene oron-ni } \\
\text { Qurdudun türgen iregtün }\end{array}$ & $\begin{array}{l}\text { Qorin dörben orod ba } \\
\text { [Q]ota ayil-dur abču } \\
\text { Qutuү ene oron-dur } \\
\text { Qurdun qurdun iregtün. }\end{array}$ & $\begin{array}{l}\text { С двадцати четырех сторон, } \\
\text { Со всех аилов и городов, } \\
\text { В это святое место, } \\
\text { Соизвольте скорее явиться! }\end{array}$ \\
\hline
\end{tabular}

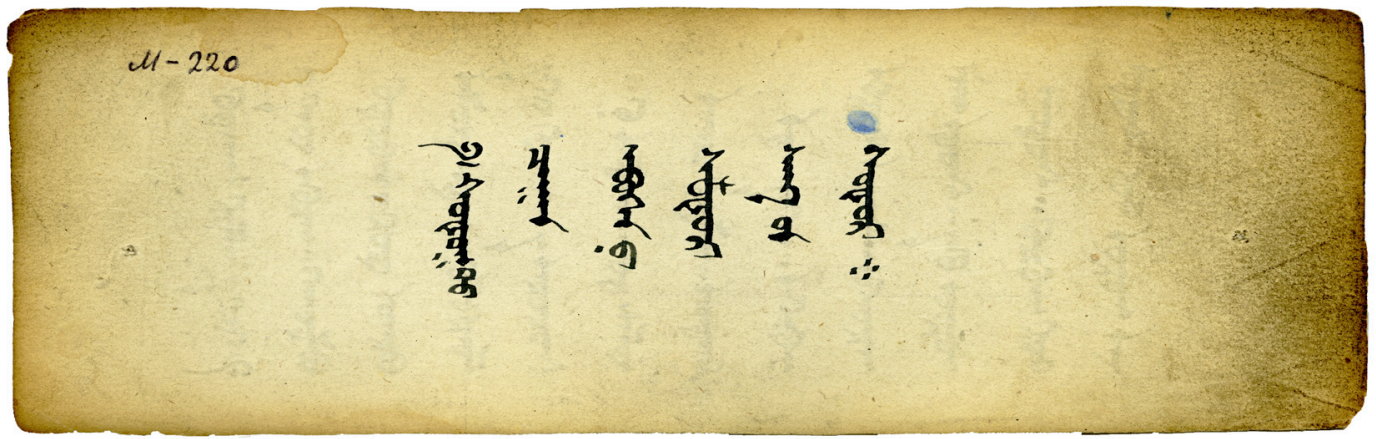

Фото 2. Титульный лист 1r. рукописи М-220 «Сутра святого Белого старца. Сутра санга». Из фонда Национального музея им. Алдан-Маадыр Республики Тыва.

Photo 2. Page 1r. of the manuscript M-220 «Sutra of the Holy White Old Man. Sutra sang». From the collections of the Aldan Maadyr National Museum of the Republic of Tuva.

Вторая рукопись из Тувы под шифром М-220 названа «Сутра святого Белого старца. Сутра санга»

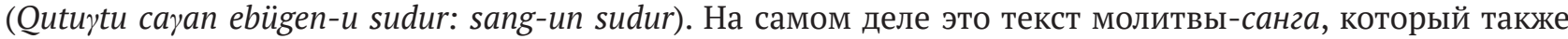
соотносится с текстом молитвы Мэргэн-гегена.

Рукопись М-220 также имеет незначительные расхождения с текстом, опубликованным В. Хайссигом, в виде различного написания слов и пропуска строк. Приведем для примера четвертый раздел молитвы-санга - «Восхваление Белого старца».

\begin{tabular}{|c|c|c|}
\hline$M-220$ & № XXIII [Heissig 1966] & Перевод \\
\hline \multicolumn{3}{|c|}{ IV. Восхваление Белого старца } \\
\hline 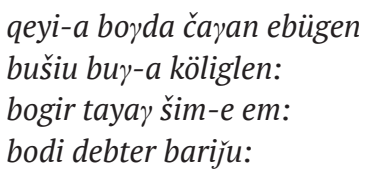 & 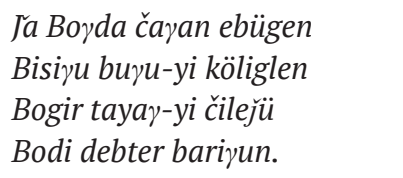 & $\begin{array}{l}\text { Святой Белый старец, } \\
\text { Своего оленя оседлавщий, } \\
\text { Резной посох, экстракт лекарств, } \\
\text { Святую книгу держащий, }\end{array}$ \\
\hline 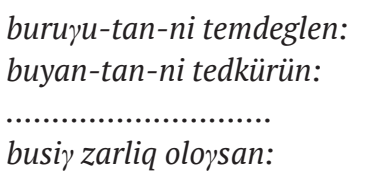 & 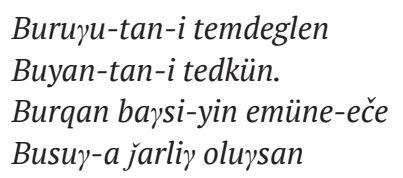 & $\begin{array}{l}\text { Отмечающий грешников, } \\
\text { Опекающий праведников. } \\
\text { Пред ликом учителя Будды } \\
\text { Праведную речь произнесший, }\end{array}$ \\
\hline 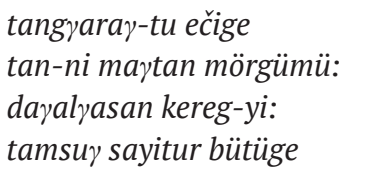 & 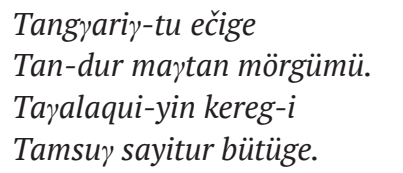 & $\begin{array}{l}\text { Облаченный клятвой отец, } \\
\text { Восхваляю и преклоняюсь вам! } \\
\text { Благовидные деяния } \\
\text { С желанной радостью воплощай! }\end{array}$ \\
\hline
\end{tabular}




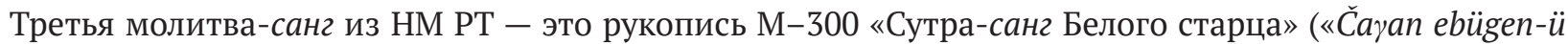
sang-un sudur orosiba»). Структурно молитва выстроена по той же общей для всех сангов схеме, но по содержанию она уже отличается от двух предыдущих текстов.

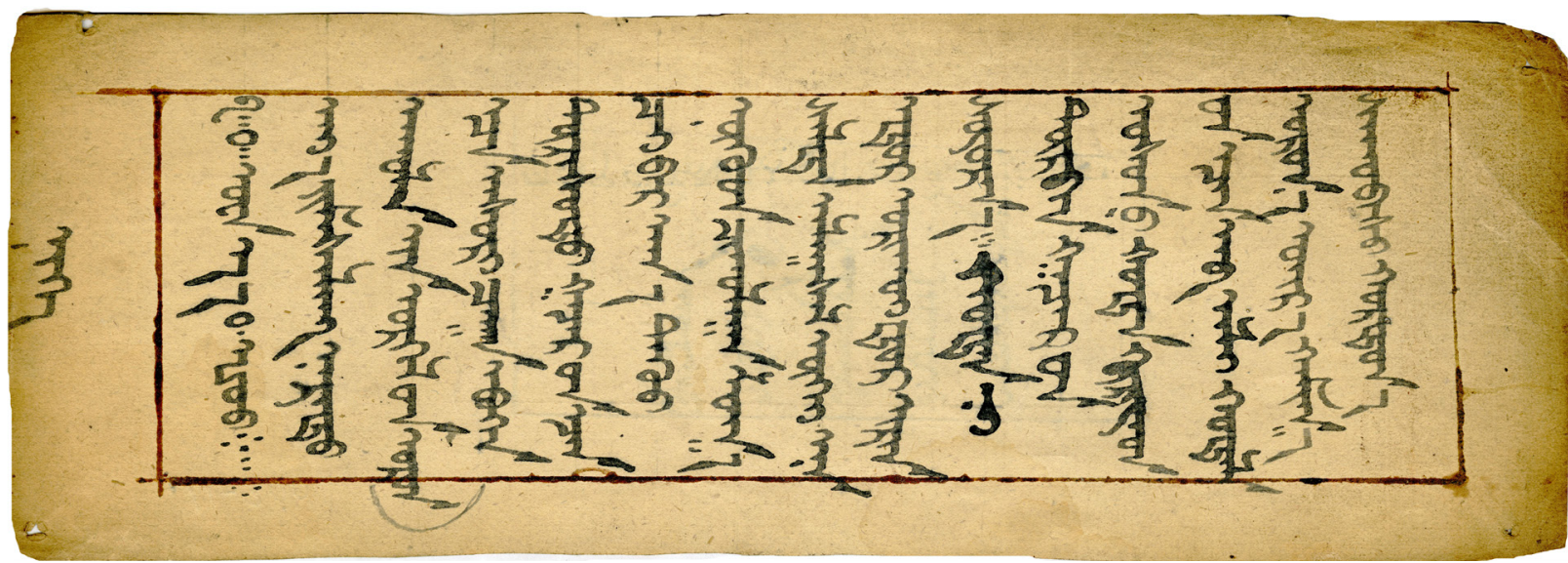

Фото 3. Лист 1v. рукописи М-300 «Сутра-санг Белого старца».

Из фонда Национального музея им. Алдан-Маадыр Республики Тыва.

Photo 3. Page 1v. of the manuscript M-300 «Sutra-sang of the White Old Man».

From the collections of the Aldan Maadyr National Museum of the Republic of Tuva.

Текст этой молитвы соотносится с образцом № XIX в публикации В. Хайссига и типом В по классификации Х. Футаки. Разночтения с текстом № XIX незначительные, но они есть. К примеру, в разделе II. «Призывание Белого старца и других божеств».

\begin{tabular}{|c|c|c|}
\hline$M-300$ & Heissig XIX & \\
\hline 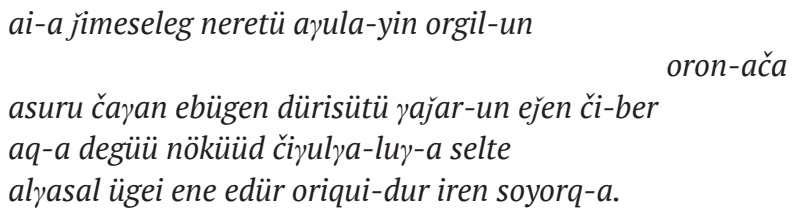 & 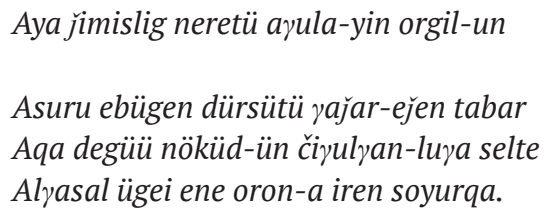 & oron-ača. \\
\hline 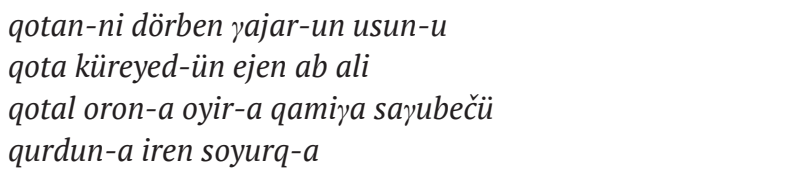 & 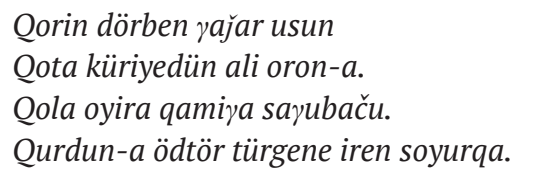 & \\
\hline
\end{tabular}

Такие разночтения достаточно частое явление для монгольских текстов. Все зависело от уровня подготовленности и внимательности переписчика текста. К примеру, разное написание слов ǰmeseleg / jimislig; dürisütü / dürsütü; пропуски слов - čavan ebügen (Белый старец) / ebügen (старец); потеря окончания слова zajar-un ејеп (хозяин земли) / yajar-ејеn (хозяин-земля); замена одних слов на другие - či-ber (ты) / tabar (вы); qotan-ni dörben (четыре города) / Qorin dörben (двадцать четыре).

Подобные расхождения есть и в других разделах. K примеру, в разделе IV. «Восхваление Белого стария»».

\begin{tabular}{|c|c|}
\hline$M-300$ & Heissig XIX \\
\hline 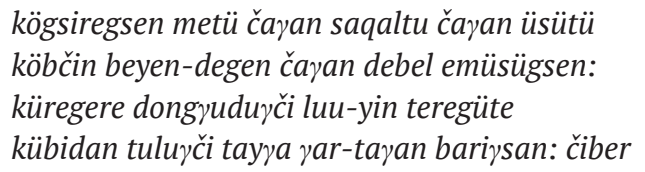 & 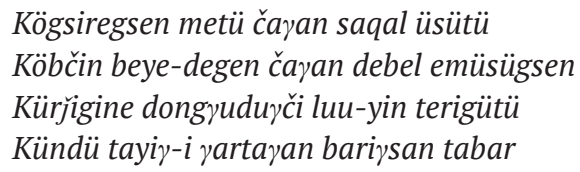 \\
\hline
\end{tabular}


erketü burqan baүši-yin nidün-e emün-e

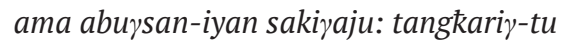
nigen buyan-ni üyledügci ken-i bügesü ečige metü tedkügči ürü šiyal-tu:

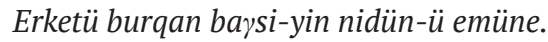

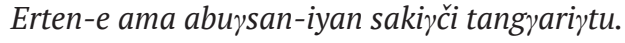
Erkin buyan üiledügči ken bügesü Ečige metü tedkügči üre sayintu. eldeb nigül üyledügči-yin nereši erlig qajan metü bičig-tür bičiju: ene yirtinčü-yin amitan-u üile-yin ači ür-e-yi

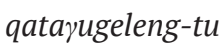
aldal ügei medegči.

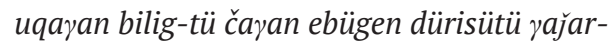
un ejen

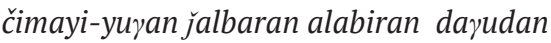

Eldeb nigüli üiledügči-yin neres-i

Erlig qayan metü bičig-tür bičigeči

Ene yirtinčü-yin amitan-u üiles-yin ači üre-yi qataručil-tu üneger medegči.

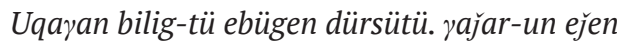

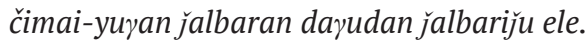

jalbiraju ele.

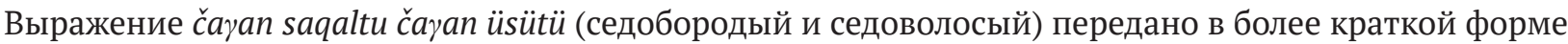

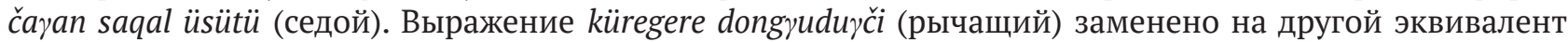

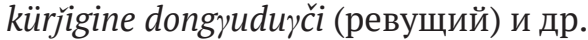

Одной из особенностей графики текстов из Тувы является то, что в подавляющем большинстве случаев графема «క̌` во всех позициях отмечена короной (титм), в то время как для старомонгольской графики это не характерно. По всей видимости, это следствие влияния ойратского «ясного письма».

Таким образом, в трех рукописях молитв Белому старцу из НМ РТ содержатся два варианта сангов, известных по классификациям В. Хайссига и Х. Футаки как № XIX или тип В и № XXIII или тип А.

\section{Структура текстов «Сутры Белого старцая}

В отечественном монголоведении «Сутру Белого старца» впервые в научный оборот ввел А. М. Позднеев, опубликовавший русский перевод текста в 1887 г. (Позднеев, 1887).

Н. Н. Поппе, описывая монгольские рукописи Института востоковедения Академии наук СССР, выделил несколько текстов в отдельный раздел «Культ Белого старца», в котором описал четыре монгольских текста и одну рукопись на «ясном письме» (Поппе, 1932: 187). Рукописи, описанные Н. Н. Поппе, служат подтверждением того, что тексты молитв-сангов и «Сутры Белого старца» воспринимались верующими как единый текст. Поэтому на титульном листе сутр встречается указание на то, что это текст санга и наоборот. К примеру, из известных нам четырнадцати рукописей текста сутры из Синьцзяна девять были названы сангами. Из трех текстов сутры из Западной Монголии, лишь одна указана как санг. Из тринадцати рукописей из России сангом названы только две рукописи из коллекции Института востоководения РАН, происхождение которых не совсем ясно (были ли они приобретены у ойратов Монголии или у калмыков на Волге).

На титульном листе рукописи обычно указывается краткое название сочинения, а в самом тексте указывается полное наименование. Все рукописи «Сутры Белого старца» имеют то же название, которое указано у Н. Н. Поппе - «Сутра Усмирителя и покорителя [духов-хозяев] земли и воды» («үazar usuni nomojodxon darulun čidaqči neretü sudur»). Этот эпитет Белого старца, опосредованно напоминающий эпитеты самого Будды, неизменно присутствует в названии всех текстов псевдосутры. Однако на титульном листе в маргинальном названии текстов он по-прежнему будет назван Белым старцем

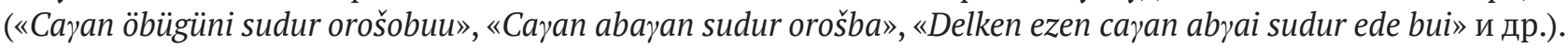

Все тексты «Сутры Белого старца» имеют одну общую структуру. Подобно текстам молитв-сангов структура сутры также состоит из последовательных логично связанных между собой разделов. Однако в отличие от сангов, содержание разделов сутры не допускает варьирования и остается неизменным. Все различия в текстах сутр связаны с пропусками, заменой, своеобразным написанием тех или иных слов. В содержательном плане различаются лишь вступительная и заключительная формулы поклонения. 
Знание этой структуры дает возможность членить текст сутры на составные части для проведения анализа его содержания.

\section{I. Вступительная часть}

- формула поклонения (Трем драгоценностям или Манджушри),

- название произведения на санскрите (может не быть), тибетском (может не быть), китайском (может не быть) и монгольском языках,

- формула поклонения всем буддам и бодхисатвам,

- традиционная формула начала сутр (eyin kemen mini sonosoqsan nige caqtu).

\section{II. Встреча Будды с Белым старцем}

- обстоятельства, которые составляют фон действия (прогулка Будды в окружении Ананды и других учеников, будд и бодхисаттв на горе Плодовой / Фруктовой),

- встреча с Белым старцем (портретное описание и обязательный атрибут - посох с головой дракона),

- обращение Будды к Белому старцу.

\section{III. Монолог-ответ Белого старца}

- обозначение своих функций (владыка всего мира и ландшафтных духов-хозяев),

- определение благих деяний живых существ,

- определение наказания за неправедные деяния.

\section{IV. Дхарани Будды для Белого старца}

- принятие обета перед Буддой и получение от него мантры,

- о пользе начитывания мантры,

- о пользе чтении мантры и переписывания сутры.

\section{V. Заключительная часть}

- традиционная формула завершения сутры,

- заключительная формула благопожелания (мантра шести слогов и/или санскритская формула «sarva mam gha lam»).

Две другие рукописи из НМ РТ представляют собой сборники, состоящие из двух традиционных видов текстов - молитвы-санга и «Сутры Белого старца». При этом рукопись М-323 озаглавлена как

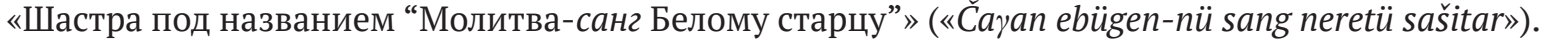

Сборник открывается текстом молитвы-санг, которая соотносится с текстом № XIX по классификации В. Хайссига и типом В по классификации Х. Футаки. Различия в текстах идентичны вышеуказанным разночтениям.

На середине л. 3r начинается текст «Сутры Белого старца», который открывается формулой поклонения Трем драгоценностям, указанием санскритского (enedkey-un keleber: ju suve ha), тибетского

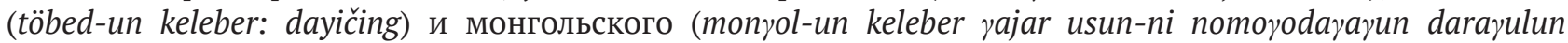
čidajči neretu sudur) названий произведения. В конце рукописи на л. 6r. присутствует традиционная фраза о завершении текста, в которой указано более полное название сочинения - «Сутра махаяны под названием “Почтительная речь Старца, усмирителя и покорителя [духов-хозяев] земли и воды”

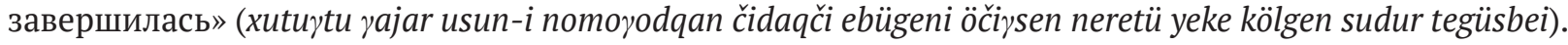

Содержательная часть сутры идентична содержанию ойратского текста № XXI «Xutuqtu ča sudur orošiboi», опубликованного В. Хайссигом.

Содержание второго рукописного сборника М-324 «Сутра под названием молитва-санг Белому

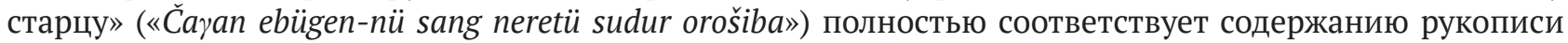
M-323. Несмотря на разные названия оба сборника восходят к одному источнику.

Так, среди известных нам 32 текстов «Сутры Белого старца» и семи текстов молитвы-санг на «ясном письме» из России, Монголии и Китая оказалось только шесть рукописных сборников. При этом четыре из них состояли из двух разных текстов молитв-сангов. Два других - включали до шести текстов молитв-сангов и текст «Сутры Белого старца». Однако ни один из них не состоял из двух видов текстов культа Белого старца - молитвы-санга и «Сутры Белого старца». Только в тувинской коллекции монгольских рукописей нам удалось обнаружить два сборника, в которых представлены два разных вида текстов, принадлежащих культу Белого старца. 


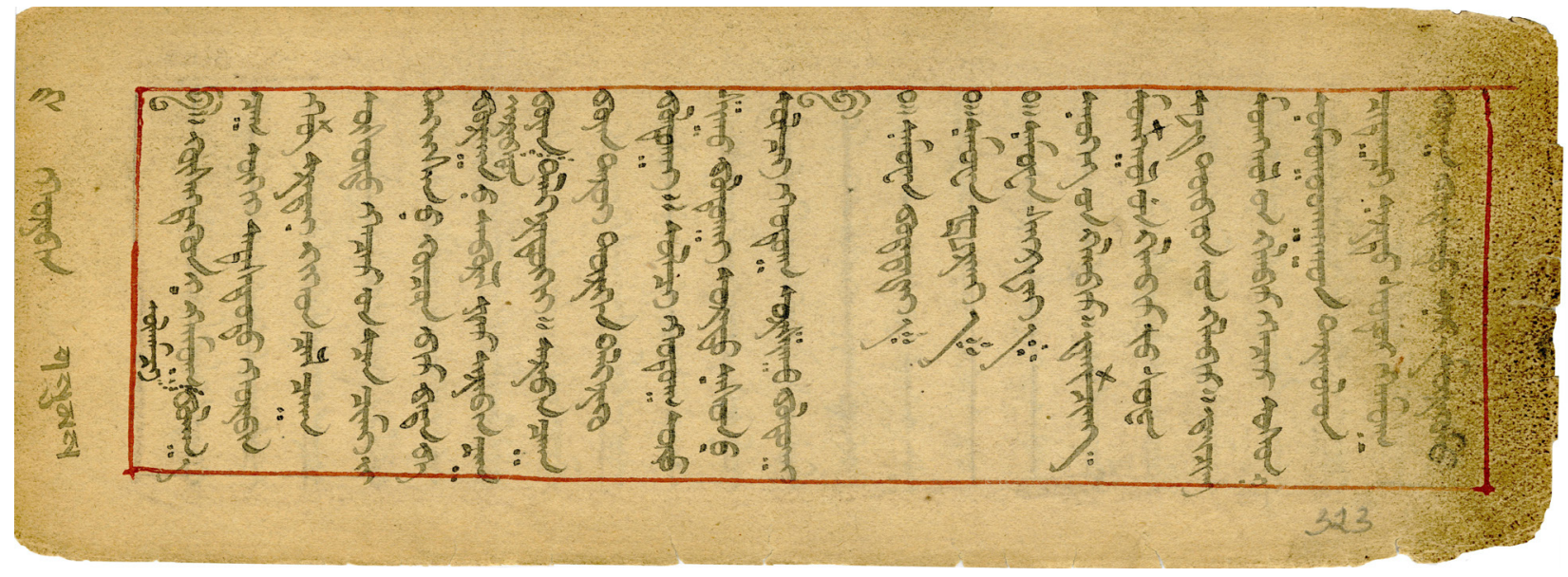

Фото 4. Лист 3r. рукописи М-323 «Шастра под названием “Молитва-санг Белому стариу”». Из фонда Национального музея им. Алдан-Маадыр Республики Тыва.

Photo 4. Page 3r. of the manuscript M-323 «A shastra titled "Prayer-sang to the White Old Man"》. From the collections of the Aldan Maadyr National Museum of the Republic of Tuva.

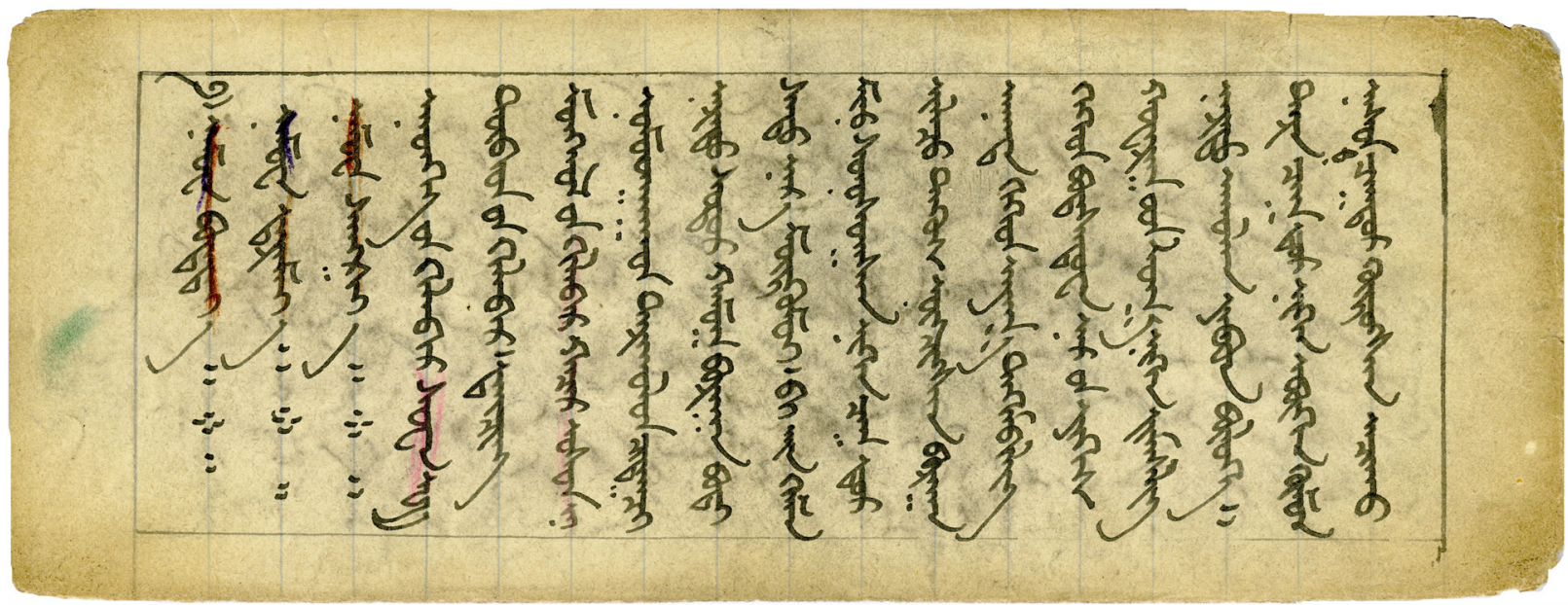

Фото 5. Лист 3v. рукописи М-324 «Сутра под названием “Молитва-санг Белому стариу”». Из фонда Национального музея им. Алдан-Маадыр Республики Тыва.

Photo 5. Page 3v. of the manuscript M-324 «A sutra titled "Prayer-sang to the White Old Man"». From the collections of the Aldan Maadyr National Museum of the Republic of Tuva.

\section{Заключение}

Таким образом, значимость и широкая распространенность сделали культ Белого старца особым феноменом религиозно-духовной культуры многих народов Сибири, Монголии и Китая. С этим культом связаны разнообразные обрядовые, текстологические и иконографические традиции.

В Национальном музее им. Алдан-Маадыр Республики Тыва находятся два вида текстов, связанных с культом Белого старца. Среди них обнаружены тексты пяти молитв-сангов, известные по классификации В. Хайссига и Х. Футаки и два текста «Сутры Белого старца».

Соседство с кочевьями ойратов и влияние традиции «ясного письма» сказалось на ряде текстов. Одной из особенностей графики текстов из Тувы является то, что в большинстве текстов графема «క̌» во всех позициях отмечена короной (титм), что является характерным признаком «ясного письма». Тексты рукописей служат подтверждением того, что культ Белого старца был в свое время широко распространен на территории Тувы. 


\section{Благодарности}

Выражаю признательность сотрудникам Национального музея им. Алдан-Маадыр Республики Тыва: хранителю Алдарме Чулдумовне Монгуш и заместителю директора Хулербену Кок-ооловичу Кадыг-оолу - за помощь в ознакомлении с копиями рукописей.

\section{СПИСОК ЛИТЕРАТУРЫ}

Герасимова, К. М. (1980) О некоторых аспектах ассимиляции добуддийских культов по тибетским обрядникам // Буддизм и средневековая культура народов Центральной Азии / отв. ред. К. М. Герасимова. Новосибирск : Наука. 176 с. С. $54-82$.

Дулам, С. (2018) Монголын буриад бөө нэрийн Цагаан өвгөний шүтлэг, тахилга [Культ и почитание Белого старца шаманами монгольских бурят] // Эрдэм шинжилгээний өгүүлэл [Сборник научных статей]. Улаанбаатар: Монгол улсын их сургууль [Монгольский государственный университет]. I боть. Домог зүй, бөө мөргөлийн судалгаа [Т. І. Исследование мифов и шаманизма]. 496 с. С. 404-419. (На монг. яз.).

Ламаизм в Бурятии XVIII - начала XX века: Структура и социальная роль культовой системы (1983) / отв. ред. Н. В. Абаев. Новосибирск : Наука, Сиб. Отделение. 235 с.

Позднеев, А. М. (1887) Очерки быта буддийских монастырей и буддийского духовенства в Монголии в связи с отношением сего последнего к народу. СПб. : Типография Императорской академии наук. 492 с.

Поппе, Н. Н. (1932) Описание монгольских «шаманских» рукописей Института востоковедения // Записки Института востоковедения АН СССР. Т. І./ ред. изд. С. Ф. Ольденбург. Л. : Изд. Академии наук СССР. 321 с. С. $151-200$.

Самбудорж, О. (1997) Хэл зохиолын хүрээлэнгийн тод үсгийн номын бүртгэл. Сан тахилгын судар [Каталог рукописей на «ясном письме» Института языка и литературы. Рукописи молитв-сангов]. Уланбаатар: ШУА-ийн Хэл Зохиолын хүрээлэн (Институт языка и литературы АНМ). 108 х. (На монг. яз.).

Birtalan, A. (2020) Ritual Texts Dedicated to the White Old Man with Examples from the Classical Mongolian and Oirat (Clear Script) Textual Corpora // Sources of Mongolian Buddhism / Ed. by A. Vesna. Wallace. Oxford : University Press. 544 p. P. 269-293.

Heissig, W. (1966) Mongolische Volksreligiose und folklorische Texte. Wiesbaden : Franz Steiner Verlag. 256 p.

Futaki, H. (2005) Classification of Texts Related to the White Old Man // Quastiones Mongolorum Disputatae No. 1. P. 35-46.

Galdan, Do. (2013) Suryal šilüg kiged sang takil [«Стихотворные поучения и молитвы-санги»]. Ürumči : Šinǰiyang-un arada-un keblel-un xoryi-a. 378 х. (На монг. яз.).

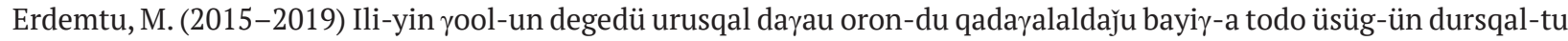
bičig-ün sudulul [«Исследование памятников “ясного письма”, хранящихся в верховьях реки Или»] : in 50 vol. НuhHoto : Öbör mongrol-un soyol-un keblel-un horyi-а. (На монг. яз.).

Sazykin, A. (1994) Catalogue of the Mongol manuscripts and xylographs preserved in the library of the Tuvan Ethnological museum "Sixty Heroes" // Acta Orientalia Academiae Scientarium Hungaricae. T. XLVII, Fas. 3. Budapest : Academiai Kiado. 467 p. P. 327-407.

Śarközi, A. (1983) Incense-offering to the White Old Man // Documenta Barbarorum. Festschrift für Walter Heissig zum 70. Geburtstag. Veröffentlichungen der Societas Uralo-Altaica Band. Wiesbaden: Otto Harrassowitz Verlag. 435 p. P. 357-369.

Дата поступления: 14.01.2020 2.

\section{REFERENCES}

Gerasimova K. M. (1980) O nekotorykh aspektakh assimiliatsii dobuddiiskikh kul'tov po tibetskim obriadnikam [On some aspects of assimilation of pre-Buddhist cults according to Tibetan rites]. In: Buddizm i srednevekovaia kul'tura narodov Tsentral'noi Azii [Buddhism and medieval culture of the peoples of Central Asia] / ed. by K. M. Gerasimova. Novosibirsk, Nauka. 176 p. Pp. 54-82. (In Russ.).

Dulam, S. (2018) Mongolyn buriad böö neriin Tsagaan övgönii shütleg, takhilga [The cult and veneration of the White Old Man by Buryat shamans in Mongolia]. In: Erdem shinzhilgeenii ögüülel [A collection of research articles]. Ulaanbaatar, Mongolian State University. I bot'. Domog züi, böö mörgöliin sudalgaa [Vol. I. Studies in myths and shamanism]. 496 p. Pp. 404-419. (In Mong.). 
Lamaizm v Buriatii XVIII - nachala XX veka: Struktura i sotsial'naia rol' kul'tovoi sistemy [Lamaism in Buryatia from the 18th to early 20th century: The structure and social role of the cult system] (1983) / ed. by N. V. Abaev. Novosibirsk, Nauka, Sib. Otdelenie. 235 p. (In Russ.).

Pozdneev, A. M. (1887) Ocherki byta buddiiskih monastyrei i buddiiskogo dukhovenstva v Mongolii v svyazi sotnosheniem sego poslednego $k$ narodu [Sketches of the life of Buddhist monasteries and clergy in Mongolia, in connection with the latter's relation to the people]. St. Petersburg, Typography of the Imperial Academy of Sciences. 492 p. (In Russ.).

Poppe, N. N. (1932) Opisanie mongol'skikh «shamanskikh» rukopisei Instituta vostokovedeniia [Description of the Mongolian «shamanic» manuscripts at the Institute of Oriental Studies]. In: Zapiski Instituta vostokovedeniia AN SSSR [Notes of the Institute of Oriental Studies of the USSR Academy of Sciences] / ed. by S. F. Ol'denburg. Leningrad, Izd. Akademii nauk SSSR. Vol. I. 321 p. Pp. 151-200. (In Russ.).

Sambudorzh, O. (1997) Khel zokhiolyn khüreelengiin tod üsgiin nomyn bürtgel. San takhilgyn sudar [Catalogues of manuscripts on the «clear script» of the Institute of Language and Literature]. Ulanbaatar, Institute of Language and Literature of the Academy of Sciences of Mongolia. 108 p. (In Mong.).

Birtalan, A. (2020) Ritual Texts Dedicated to the White Old Man with Examples from the Classical Mongolian and Oirat (Clear Script) Textual Corpora. In: Sources of Mongolian Buddhism / Ed. by A. Vesna. Wallace. Oxford, University Press. 544 p. P. 269-293.

Heissig, W. (1966) Mongolische Volksreligiose und folklorische Texte. Wiesbaden, Franz Steiner Verlag. 256 p.

Futaki, H. (2005) Classification of Texts Related to the White Old Man. Quastiones Mongolorum Disputatae, no. 1, pp. 35-46.

Galdan, Do. (2013) Surral šilüg kiged sang takil Didactic Poems and Offerings]. Ürumči, Šinjiyang-un arada-un keblel-un xoryi-a. 378 p. (In Mong.).

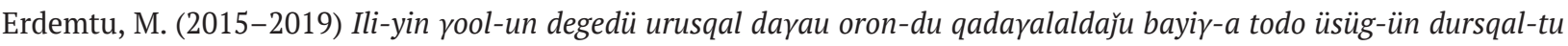
bičig-ün sudulul The Collection of Written Sources in the Clear Script Preserved in the Ili River Basin] : in 50 vol. Huh-Hoto, Öbör mongyol-un soyol-un keblel-un horyi-a. (In Mong.).

Submission date: 14.01.2020. 